\title{
DIVERSITY OF FUNGI COLONIZING LEAVES OF RHODODENDRON (Rhododendron L.) CUTTINGS
}

\author{
Barbara Kierpiec-Baran, Małgorzata Żołna, Maria Kowalik \\ Department of Plant Protection, Faculty of Horticulture, University of Agriculture in Krakow \\ Al. 29-Listopada 54, 31-425 Kraków, Poland \\ e-mail: barbara.kierpiec@wp.pl
}

Received: 30.01 .2013

\begin{abstract}
Rhododendrons (Rhododendron L.) are shrubs whose attractiveness is determined by their multi-coloured flowers and evergreen leaves. Necroses visible on the leaves of rhododendron cuttings diminish the suitability of nursery material for marketing. These symptoms are most frequently caused by fungi. The investigations were conducted in 2010-2011 in an ornamental shrub nursery to identify fungi colonizing the phyllosphere of rhododendron cuttings and causing leaf necroses. The material for analysis consisted of leaves of 11 rhododendron cultivars. 550 leaves were collected from 110 half-yearold cuttings for mycological analysis. Over 350 fungal colonies belonging to 15 species were isolated from the leaves of rhododendron cuttings. The dominants included: Pestalotiopsis sydowiana, Trichoderma koningii and Alternaria alternata. The influents included: Aspergillus brasiliensis, Mucor hiemalis $\mathrm{f}$. hiemalis, Epicoccum nigrum, Sordaria fimicola and Umbelopsis isabellina. A large majority of the fungi preferred the phyllosphere environment of Yakushima rhododendron (R. yakushimanum) cultivars 'Sneezy' and 'Golden Torch' as well as of the large-flowered cultivars 'Flautando', 'Dominik', and 'Simona'. The phyllosphere of the large-flowered cultivars 'Bernstein', 'Nova Zembla', and 'Goldbuckett' was a reservoir for many fungal colonies and fungi species. The cultivars less susceptible to colonization by fungi and the most promising for planting in green areas and home gardens are the large-flowered cultivars 'Bernstein', 'Nova Zembla', 'Goldbuckett', 'Rasputin', and 'Roseum Elegans'.
\end{abstract}

Key words: Rhododendron L., phyllosphere necroses, mycological analysis

\section{INTRODUCTION}

Evergreen rhododendron (Rhododendron L.) shrubs owe their attractiveness not only to flowers enchanting with their colours and smell, but also to the leaves forming the canopy. Necroses greatly decreasing the suitability of nursery material for marketing have been diagnosed on leaves of rhododendron cuttings in production nurseries. Symptoms of discolouration, leaf spot and necroses resulting in dieback and leaf fall in long-standing shrubs were presented in the papers by Kowalik and Muras [1] as well as by K o w a li k et al. [2-4], whereas the agents of leaf infection (fungi and fungus-like organisms) were identified in the works of Kow a lik $[5,6]$ and Kow a lik et al. $[7,8]$.

Determining the agents causing necroses on the leaves of rhododendron cuttings provides the possibility to select cultivars less susceptible to colonization by pathogens causing dieback and falling of leaves to be planted in green areas and home gardens.

The aim of the study was to identify fungi living in the phyllosphere of rhododendron cuttings and causing leaf necrotic spots.

\section{MATERIALS AND METHODS}

The research was conducted in 2010-2011 on cuttings of evergreen rhododendron (Rhododendron L.) in an ornamental shrub nursery in the region of Silesia.

The analyzed material consisted of 11 rhododendron cultivars: $R$. brachycarpum 'Flautando', $R$. calophytum 'Dominik', $R$. catawbiense 'Nova Zembla', 'Rasputin', 'Roseum Elegans', 'Simona', $R$. dichroantum 'Bernstein', $R$. forrestii 'Baden Baden', $R$. wardii 'Goldbuckett', R. yakushimanum 'Golden Torch' and 'Sneezy'. 550 leaves showing necrosis were collected from 110 half-year-old cuttings and used for mycological analysis. The analysis was conducted using standard methods applied in mycology [5]. Fungi were isolated from the border of the living and necrotic tissue. 
Isolated fungal colonies were classified using the following keys: Dom sch et al. [9], E11 is and E 11 is [10], G u b a [11] and S u t t on [12]. The system of Kirk et al. [13] was accepted as the basis of the classification and the authors' epithets were quoted by the fungi names after Index Fungorum [14].

In terms of the proportional share of species in the whole community of isolated fungi, division was made after K o w a lik [15] into dominants, influents and accessory fungi.

\section{RESULTS}

Over 350 fungal colonies related to 15 species were isolated from the leaves of evergreen rhododendron (Rhododendron L.) cuttings showing necrosis.

Fungi that colonized the leaves most frequently were the following: Pestalotiopsis sydowiana (62.80\%), Trichoderma koningii (14.77\%) and Alternaria alternata (constituting $6.25 \%$ of the entire community of isolated fungal colonies). These fungi, classified as dominants, made up almost $84 \%$ of the total fungi community. Aspergillus brasiliensis, Mucor hiemalis f. hiemalis, Epicoccum nigrum, Sordaria fimicola and Umbelopsis isabellina, classified as influents, occurred less frequently, accounting for $12 \%$ of the entire community. Harzia velata, Mortierella horticola, Mortierella hyalina, Penicillium expansum, Penicillium verrucosum var. verrucosum, Boeremia exigua var. exigua and Trichoderma viride were present sporadically and made up about $4 \%$ of the identified isolates (Table 1).

Between 12 and 51 colonies belonging to between 3 and 7 species were isolated from the leaves of cuttings of the individual rhododendron cultivars. The highest number of fungal colonies were identified on the leaves of $R$. yakushimanum 'Sneezy', a slightly lower number was isolated from the large-flowered cultivars $R$. brachycarpum 'Flautando', $R$. calophytum 'Dominik', and $R$. catawbiense 'Simona'. A comparable number of fungal colonies were isolated from Forrest's 'Baden-Baden' and Yakushima 'Golden Torch' rhododendrons. The least number of colonies and fungal species were identified on the leaves of the largeflowered varieties $R$. dichroantum 'Bernstein' and $R$. catawbiense 'Nova Zembla'. The greatest diversity of fungi was observed in the phyllosphere of largeflowered rhododendrons $R$. catawbiense 'Simona' and R. yakushimanum 'Sneezy' (Table 2).

Table 1

Fungi isolated from leaves of rhododendron cuttings

\begin{tabular}{|c|c|c|c|}
\hline \multirow{2}{*}{ Fungus } & \multicolumn{2}{|c|}{ Frequency of occurrence } & \multirow{2}{*}{$\begin{array}{c}\text { Percentage [\%] } \\
2010-2011\end{array}$} \\
\hline & 2010 & 2011 & \\
\hline Alternaria alternata (Fr.) Keissl. & 14 & 8 & 6.25 \\
\hline Aspergillus brasiliensis Varga, Frisvard \& Samson & 7 & 8 & 4.26 \\
\hline Boeremia exigua (Desm.) Aveskamp, Gruyter \& Verkley var. exigua & - & 3 & 0.85 \\
\hline Epicoccum nigrum Link & 5 & 2 & 1.99 \\
\hline Harzia velata (Onions \& D. Jones) Hol.-Jech. & 1 & - & 0.28 \\
\hline Mortierella horticola Linnem. & 3 & - & 0.85 \\
\hline Mortierella hyalina (Harz) W. Gams & 2 & - & 0.57 \\
\hline Mucor hiemalis f. hiemalis Wehmer & 10 & 2 & 3.41 \\
\hline Penicillium expansum Link & - & 2 & 0.57 \\
\hline Penicillium verrucosum var. verrucosum Dierckx & 1 & - & 0.28 \\
\hline Pestalotiopsis sydowiana (Bres.) B. Sutton & 118 & 103 & 62.78 \\
\hline Sordaria fimicola (Roberge ex Desm.) Ces. \& De Not. & 6 & - & 1.70 \\
\hline Trichoderma koningii Oudem. & 32 & 20 & 14.77 \\
\hline Trichoderma viride Pers. & 1 & - & 0.28 \\
\hline Umbelopsis isabellina (Oudem.) W. Gams & 1 & 3 & 1.14 \\
\hline Total & 201 & 151 & 100.00 \\
\hline
\end{tabular}


Table 2

Number of fungal colonies and species on the leaves of cuttings of particular rhododendron cultivars

\begin{tabular}{|c|c|c|}
\hline Species/Cultivar & Number of fungal colonies & Number of fungal species \\
\hline R. brachycarpum ,Flautando' & 50 & 3 \\
\hline R. calophytum ,Dominik' & 44 & 3 \\
\hline R. catawbiense ,Nova Zembla' & 12 & 3 \\
\hline R. catawbiense ,Rasputin' & 16 & 4 \\
\hline R. catawbiense ,Roseum Elegans' & 28 & 5 \\
\hline R. catawbiense ,Simona' & 42 & 7 \\
\hline R. dichroantum ,Berstein' & 12 & 3 \\
\hline R. forrestii ,Baden-Baden’ & 41 & 5 \\
\hline R. wardii ,Goldbuckett' & 13 & 4 \\
\hline R. yakushimanum, Golden Torch' & 43 & 5 \\
\hline R. yakushimanum ,Sneezy' & 51 & 6 \\
\hline
\end{tabular}

\section{DISCUSSION}

A comparison of the fungal communities isolated from diseased cuttings and leaves of long-standing rhododendron shrubs revealed that A. alternata and Pestalopsis sydowiana, syn. Pestalotia sydowiana $[2,3,6,8]$ dominated in the populations. Frequently occurring Botrytis cinerea, Septoria azalea, Gloeosporium rhododendri and fungi of the genera Mortierella and Mucor were also observed in these communities. These fungi can be considered to play the main role in the leaf necrotizing process and in infection of rhododendron inflorescence buds $[1,4,8,16]$.

Botrytis cinerea, Septoria azalea, Gloeosporium rhododendri and fungi of the following genera: Aspergillus, Chaetomium, Cladosporium, Cylindrocarpon, Fusarium, Humicola, Penicilium, Phialophora, Phoma, Rhizoctonia and other $[5,6,8]$, were also found on the leaves with necrotic spots of rhododendrons and azalea of many years' growth, whereas the same fungi did not occur in the phyllosphere of rhododendron cuttings. Numerous occurrences of Trichoderma koningii were recorded on the leaves of rhododendron cuttings, whereas the fungus was observed only sporadically on azalea leaves [7].

The phyllosphere of the cultivars $R$. calophytum 'Dominik', $R$. yakushimanum 'Sneezy', 'Golden Torch' and $R$. catawbiense 'Simona' was an environment favourable for toxigenic fungi $A$. alternate and A. brasiliensis, syn. A. niger., known for their ability to produce tentoxin and cause leaf dieback in many crops $[17,18]$.

Isolating numerous colonies of Trichoderma koningii from diseased leaves of the cultivars $R$. catawbiense 'Roseum Elegans', R. yakushimanum 'Sneezy', $R$. dichroantum 'Bernstein', $R$. brachycarpum 'Flautando', $R$. yakushimanum 'Golden Torch, $R$. forrestii
'Baden Baden' and R. catawbiense 'Simona' seems to be evidence of the virulence and expansiveness of this species known to sporulate abundantly.

Individual cases of the fungus Harzia velata, isolated from the leaves of rhododendron cuttings, have not been found so far in the phyllosphere of evergreen rhododendrons or leaf dropping azaleas.

In the literature of the subject, Phytophthora spp. fungus-like organisms are reported among the most dangerous pathogens that worsen the health of rhododendrons in nurseries [19]. The conducted mycological analysis did not find these pathogens either on the leaves or on the root system of cuttings, which is evidence that the tested material was acquired for nursery production.

The presence of $P$. sydowiana, A. alternata, E. nigrum, B. exigua var. exigua and saprophytes of the genera Mortierella, Mucor, Penicillium, Sordaria and Trichoderma on the infected cutting leaves points to their pathogenicity $[1,5-8]$ towards plants in the initial period of cultivation.

A vast majority of the fungi preferred the phyllosphere environment of the Yakushima rhododendron cultivars «Sneezy〉 and «Golden Torch〉 and of the largeflowered cultivars $R$. brachycarpum 'Flautando', $R$. calophytum 'Dominik', and $R$. catawbiense 'Simona'. The phyllosphere environment of the large-flowered varieties $R$. dichroantum 'Bernstein', $R$. catawbiense 'Nova Zembla', and $R$. wardii 'Goldbuckett' was the reservoir for few colonies and species of fungi. The cultivars that were less susceptible to fungal colonization and best suited for planting in green areas and home gardens are the following varieties of largeflowered rhododendrons: $R$. dichroantum 'Bernstein', $R$. catawbiense 'Nova Zembla', 'Rasputin', 'Roseum Elegans', and $R$. wardii 'Goldbuckett'. 
The obtained results reveal the species diversity of fungi colonizing leaves of evergreen rhododendron cuttings and different species as well as they show the quantitative composition of fungal communities isolated from leaves of cuttings and long-standing shrubs.

\section{CONCLUSIONS}

1. Leaves of rhododendron cultivars were characterized by varying susceptibility to colonization by fungi. The phyllosphere of rhododendron cuttings was dominated by Pestalotiopsis sydowiana, Trichoderma koningii, and Alternaria alternata.

2. 'Bernstein' and 'Nova Zembla' were inhabited by relatively few fungal colonies and species, which means that these cultivars are the most promising for planting in green areas and home gardens.

3. The cultivar 'Sneezy' was the most susceptible to infection by fungi causing leaf necroses, which may provide a basis for its reduction or elimination from the production of seedlings.

\section{Acknowledgements}

Research supported by the Ministry of Science and Higher Education of Poland as part of the statutory activities of the Department of Plant Protection, University of Agriculture in Kraków.

\section{Authors' contributions}

The following declarations about authors' contributions to the research have been made: concept of the study: MK, BKB; determination of specimens: $\mathrm{BKB}, \mathrm{MZ}$; writing the manuscript: $\mathrm{MK}, \mathrm{BKB}$.

\section{REFERENCES}

1. Kowalik M, Muras P. Grzyby zasiedlające opadłe liście różanecznika [Fungi occurring on the fallen leaves of rhododendron]. Rocz AR Pozn Ogrod 2007; 41: 69-73.

2. Kowalik M, Muras P, Kierpiec B, Żołna M. Zdrowotność liści różaneczników zawsze zielonych Rhododendron L. [The leaf health of the leaves of the evergreen rhododendron Rhododendron L.]. Zesz Probl Post Nauk Rol. 2010; 551: 117-123.

3. Kowalik M, Oliwa A, Paliga A. Choroby różaneczników (Rhododendron L.) na terenach zieleni Krakowa. Erica Pol. 2006; 17: 33-41.

4. Kowalik M, Żołna M, Kierpiec B. Fungi living at the fallen leaves of rhododendron Rhododendron L. Acta Sci Pol Hortorum Cultus. 2012; 11(2): 161-166.

5. Kowalik M. Fungi and fungi-like Oomycetes isolated from affected leaves of rhododendron. Acta Mycol. 2008; 43(1): 21-27. http://dx.doi.org/10.5586/am.2008.003

6. Kowalik M. Bioróżnorodność grzybów występujących w fyllosferze różanecznika zimozielonego Rhododendron
L. [Biodiversity of fungi occurring in phyllosphere of evergreen rhododendron (Rhododendron L.)]. Zesz Probl Post Nauk Rol. 2009; 539: 341-348.

7. Kowalik M, Kierpiec B, Bonio J, Żołna M. Fungi inhabiting spots and necroses on the leaves of azaleas Rhododendron L. in the Botanical Garden of The Jagiellonian University. Phytopathologia. 2011; 62: 41-48.

8. Kowalik M, Muras P, Żołna M, Kierpiec B. Grzyby wyosobnione z nekrotycznych plam na liściach różaneczników zawsze zielonych Rhododendron L. [Fungi isolated from necrotic spots on the leaves of evergreen rhododendrons Rhododendron L.]. Zesz Probl Post Nauk Rol. 2010; 554: 49-55.

9. Domsch KH, Gams W, Anderson TH. Compendium of soil fungi. London: Academic Press; 1980.

10. E1lis MB, E1lis JP. Microfungi of land plants. An identification handbook. London: Croom Helm; 1985.

11. Guba EF. Monochaetia and Pestalotia. Mycologia. 1955;47(6):920. http://dx.doi.org/10.2307/3755517

12. Sutton BC. Fungi imperfecti with pycnidia, aervuli and stromata. Kew: Commonwealth Mycological Institute; 1980.

13. Kirk PM, Cannon PF, Minter DW, Stalpers JA . Ainswort \& Bisby's dictionary of the fungi. Wallingford: CAB International; 2008.

14. Index fungorum [Internet]. 2012 [cited 2012 Jan 12]; Available from: www.indexfungorum.org.names/Names. asp

15. Kowalik M. Grzyby gleby inicjalnej industrioziemnej rekultywowanego w kierunku rolnym i leśnym zwałowiska Kopalni siarki Machów [Fungi of the initial postindustrial soil of the "Machów" Sulphur Mine dumping ground reclaimed for agricultural and forest use] [Rozprawa hab]. Zesz Nauk Akad Rol Im H Kołłątaja W Krakowie. 1993; 180: 1-78.

16. Żołna M, Kierpiec-Baran B, Kowalik M. The diversity of fungi colonizing necrotic inflorescence buds of rhododendron (Rhododendron L.). Acta Agrobot. 2013;66(2):79. http://dx.doi.org/10.5586/aa.2013.025

17. Chełkowski J, Visconti A, editors. Alternaria biology, plant diseases and metabolites. Amsterdam: Elsevier; 1992.

18. Pła żek A. Patofizjologia roślin. 140: Wydawnictwo Uniwersytetu Rolniczego w Krakowie. 2011; 140.

19. Orlikowski LB, Szkuta G. Studies on the occurrence and colonization of plants by Phytophthora ramorum in Poland. Acta Mycol. 2003;38(1-2):43-49.

\section{Różnorodność grzybów bytujących na liściach sadzonek różanecznika (Rhododendron L.)}

\section{Streszczenie}

Różaneczniki (Rhododendron L.) to krzewy, o których atrakcyjności decydują wielobarwne kwiaty oraz zimozielone liście. Na liściach sadzonek 
różaneczników widoczne są nekrozy obniżające przydatność materiału szkółkarskiego w obrocie handlowym. Symptomy te najczęściej wywoływane są przez grzyby. Celem badań prowadzonych w szkółce krzewów ozdobnych, w latach 2010-2011, była identyfikacja grzybów bytujących w fyllosferze sadzonek różanecznika i powodujących nekrozy liści. Materiał badawczy stanowiły liście 11 odmian różanecznika. Do analizy mykologicznej pobrano 550 liści ze 110 półrocznych sadzonek. Z liści sadzonek różanecznika z objawami nekroz, wyodrębniono ponad 350 kolonii grzybów należących do 15 gatunków. Do dominantów zaliczono: Pestalotiopsis sydowiana, Trichoderma koningii i Alternaria alternata. Do influentów zaklasyfikowano:
Aspergillus brasiliensis, Mucor hiemalis f. hiemalis, Epicoccum nigrum, Sordaria fimicola i Umbelopsis isabellina. Grzyby w dużej przewadze liczebnej preferowały środowisko fyllosfery odmian różanecznika jakuszimańskiego 'Sneezy' i 'Golden Torch' oraz różanecznika wielkokwiatowego: 'Flautando', 'Dominik' i 'Simona'. Środowisko fyllosfery odmian wielkokwiatowych: 'Bernstein', 'Nova Zembla' i 'Goldbuckett' było rezerwuarem dla niewielu kolonii i gatunków grzybów. Odmianami mało podatnymi na zasiedlenie przez grzyby i najlepiej rokującymi do nasadzeń w terenach zieleni i ogrodach przydomowych są odmiany wielkokwiatowe: 'Bernstein', 'Nova Zembla', 'Goldbuckett', 'Rasputin' i 'Roseum Elegans'.

Handling Editor: Elżbieta Weryszko-Chmielewska

This is an Open Access digital version of the article distributed under the terms of the Creative Commons Attribution 3.0 License (creativecommons.org/licenses/by/3.0/), which permits redistribution, commercial and non-commercial, provided that the article is properly cited. 